Article Type: Research Paper

\title{
The Effect of Socio-Economic Factors on the Individual Smoking Status: Case of Indonesia
}

\author{
Prasetyo Ardi Nugroho ${ }^{1 *}$ and Hastarini Dwi Atmanti ${ }^{2}$
}

\section{OPPEN}

AFFILIATION:

1, 2 Master Program, Faculty of Economics and Business, Universitas Diponegoro, Semarang, Indonesia.

\section{*CORRESPONDENCE:}

prasetyoardinug@gmail.com

\section{THIS ARTICLE IS AVALILABLE IN:}

http://journal.umy.ac.id/index.php/esp

DOI: $10.18196 /$ jesp.21.2.5038

\section{CITATION:}

Nugroho, P. A., \& Atmanti, H. D. (2020). The Effect of Socio-

Economic Factors on the Individual Smoking Status: Case of Indonesia. Jurnal Ekonomi \& Studi

Pembangunan, 21(2), 161-169.

\section{ARTICLE HISTORY}

\section{Received:}

10 June 2020

Reviewed:

22 June 2020

02 July 2020

Revised:

10 July 2020

02 Aug 2020

Accepted:

09 Oct 2020
Abstract: Research aims to understand the probability the status of smoking and factors that influence individual smoking status in Indonesia. The data used by Indonesian data family life survey (IFLS) 2014 and 2007. The subject of the research is individual 15 aged years or more at 24 province. The study used the sexes, age, marital status, the head of the household status, education, income and the type of individual tribes. Data processing using methods probit regression and was distinctions based on cities and villages. The result showed, sex, the head of a household and education significant impact on the probability of individuals to smoke in cities and villages. Improving education old one year reduce the probability of individuals to smoking of 1.34 percentage points in cities and 0.85 percentage points in the village area. The significance education variable negative shows that education is vital to lower prevalence of smoking.

Keywords: Indonesia Family Life Survey; Probability; Probit; Smoking Status JEL Classification: C81, D12, I15, J13

\section{Introduction}

Cigarettes consumption in the world reaches 5.8 trillion pieces, and Indonesia ranked fourth after China, Russia, and the United States with a total consumption of 240 billion pieces (Eriksen, Mackay, Schluger, Gomeshtapeh, \& Drope, 2015), making it the second-largest cigarette market in the world (WHO, 2011; Gibson, 2017). The Basic Health Research in 2007, 2010, 2013, and 2018 and survey data of National Health Indicators in 2016 shows that the prevalence of tobacco consumption (smoking and chewing) on a group of 15 years old in the last ten years has fluctuated in each period. The prevalence of tobacco consumption is above 30 percent and is still dominated by men, about 65 percent. In contrast, the prevalence of women consuming tobacco is much lower than men's.

The impact of cigarette consumption has a broad dimension on the health aspect, thereby influencing the economic aspect. According to food commodities, data from the Central Bureau of Statistics (2018) revealed that cigarette and tobacco consumption ranked fifth in monthly per capita expenditure. 
High cigarette consumption causes high expenditure, financial pressure, and a lack of money for household food needs (Siahpush, Farazi, Maloney, Dinkel, Nguyen, \& Singh, 2018). The total health expenditure due to cigarette consumption in Indonesia in 2015 was IDR 13.81 trillion (Kosen, Tharany, Kusumawardani, \& Martini, 2017).

Smoking behavior is an activity that can cause addiction. Addicted individuals will consume more cigarettes as a result of the accumulation of addictive effects. The theory of Rational Addiction developed by Becker and Murphy (1988) mentions that addiction affects the utility and pattern of individual expenditure. Addicted individuals obtain a utility equal to a certain level of consumption or unit at a time. Thus, they will need more consumption units in the future.

The effect of individual addiction caused by cigarette consumption spreads at various socioeconomic levels, including the poor. The study of cigarette consumption is often associated with poverty due to the massive cigarette consumption level in the poor or low-socioeconomic groups (Indonesian Ministry of Health, 2013). Individuals with low socioeconomic conditions have a higher chance of smoking (Nketiah-Amponsah, Affulmensah, \& Ampaw, 2018; Siahpush et al., 2018; Kusumawardani, Tarigan, Suparmi, \& Schlotheuber, 2018). Cigarette expenditure also tends to be more generous in households with low socioeconomic status (Siahpush et al., 2018).

Socioeconomic status has been regarded as an essential determinant of smoking behavior (Lantz, House, Lepkowski, Williams, Mero, \& Chen, 1998), even in developed countries (Garrett, Dube, Trosclair, Caraballo, \& Pechacek, 2011; Hiscock, Bauld, Amos, \& Platt, 2012; Nagelhout, de Korte-de Boer, Kunst, van der Meer, de Vries, van Gelder, \& Willemsen, 2012; Jamal, King, Neff, Whitmill, Babb, \& Graffunder, 2016). The relationship between socioeconomic status and smoking behavior may differ between countries with different levels of socioeconomic development (Wang, Shen, Sotero, Li, \& Hou, 2018).

The reality of smoking prevalence in most developed countries (high-income countries) is inversely proportional to the socioeconomic situation (Schaap, Kunst, Leinsalu, Regidor, Espelt, Ekholm, Helmert, Klumbiene, \& Mackenbach, 2009; Lemstra, Mackenbach, Neudorf, Nannapaneni, \& Kunst, 2009; Hosseinpoor, Parker, d'Espaignet, \& Chatterji, 2012; Bosdriesz, Mehmedovic, Witvliet, \& Kunst, 2014; Hanibuchi, Nakaya, \& Honjo, 2016). Whereas in developing countries such as India, Thailand, Malaysia, and Indonesia, socioeconomic status has a positive relationship with smoking behavior (Siahpush et al., 2008; Swe Latt, Mohd Rus, Ab Rahman, Nasreen, Phyu, \& Abd. Aziz, 2015; Barik, Rai, Gorain, Majumdar, \& Chowdhury, 2016; Ahsan, 2006).

Smoking behavior in previous studies could be influenced by several socioeconomic variables including education (Doku, Koivusilta, Rainio, \& Rimpela, 2010; Garrett et al., 2011; Nagelhout et al., 2012; Jamal et al., 2016; Siahpush et al., 2018; Wang et al., 2018; Kusumawardani et al., 2018), employment (Ahsan, 2006; Doku et al., 2010; Bosdriesz et al., 2014; Barik et al., 2016; Hanibuchi et al., 2016; Siahpush et al., 2018; Wang et al., 2018), income (Nagelhout et al., 2012; Hanibuchi et al., 2016; Wang et al., 2018), marital status (Harahap, 2003; Ahsan, 2006; John, Ross, \& Blecher, 2012; Nargis, Ruthbah, 
Hussain, Fong, Huq, \& Ashiquzzaman, 2014), gender (Ahsan, 2006; Kostova, Ross, Blecher, \& Markowitz, 2011; Nargis et al., 2014; Wang et al., 2018; Kusumawardani et al., 2018), age (Ahsan, 2006; Kostova et al., 2011; Nargis et al., 2014; Wang et al., 2018; Kusumawardani et al., 2018) and location of residence (Ahsan, 2006; Nargis et al., 2014; Nketiah-Amponsah et al., 2018; Mukong \& Tingum, 2019; Wang et al., 2018).

This research aims to determine the probability of smoking and socioeconomic factors influencing individuals to smoke. This study complements the lack of comprehensive research on smoking behavior in Indonesia using big data. Specific analysis in cities and villages becomes an update of research rarely presented in previous studies. This study contributes to providing data on the probability of smoking on various socioeconomic characteristics that can be used as the consideration for policymakers to reduce the prevalence and cigarette consumption in Indonesia.

\section{Research Method}

This research utilized secondary data obtained from the Indonesia Family Life Survey (IFLS) in a longitudinal of 24 provinces in Indonesia. Research subjects focused on individuals aged 15 years or more, namely individuals in IFLS-4 (2007) and IFLS-5 (2014) research totaling 17,992 . The dependent variable in this research was the smoking status. An individual on tribe variable determined $1=$ if smokers; and $0=$ if non-smokers. As for the independent variable cover: 1) age (age), 2) sex (gender), 3) education period (educ), 4) marital status (marital), 5) the status of the household head (hh_head), 6) income (income), and 7) tribe (ethnicity). The variable proxies are presented in Table 1.

The analysis applied in research was probit regression. Probit regression analysis is used to view the relations between qualitative and quantitative variables (category dependent and independent variables). The model was chosen because most research utilized discrete models such as the choice logit or probit multinomial logit models and the hazard model to investigate the impact of various socioeconomic factors against a choice of smoking status (Nguyen, 2012). The model in this research is presented as follows:

Smoking $=60+61$ age +62 gender +63 educ +84 marital+ 65 hh_head +66 income +67 ethnicity $+\varepsilon$ 
The Effect of Socio-Economic Factors on the Individual Smoking Status: ...

Table 1 Proxy of Research Variables

\begin{tabular}{lll}
\hline \multicolumn{1}{c}{ Variables } & & \multicolumn{1}{c}{ Description } \\
\hline Smoking probability & (smoking) & 1 if smokers; 0 if non-smokers \\
Age & (age) & Years \\
Sex & (gender) & 1 if male; 0 if female \\
Education & (educ) & Years \\
Marital status & (marital) & 1 if married; 0 if unmarried \\
Head of a household status & (hh_head) & 1 if the head of household; 0 if not \\
Income & (income) & Monthly expenditures (IDR) \\
Type of ethnicity & (ethnicity) & 1 if Java; 0 if others \\
& & 1 if Sumatera; 0 if others \\
& & 1 if Kalimantan; 0 if others \\
& & 1 if Bali \& Nusa Tenggara; 0 if others \\
& & 1 Sulawesi \& Maluku; 0 if others \\
\hline
\end{tabular}

\section{Result and Discussion}

\section{Marginal Effect}

The marginal effect indicated changes in the probability when the predictor or free variable increased a unit. In general, the regression coefficient probit could not interpret but could use the marginal effect of a free variable, and that was how large the probability of change of the variables results when changing the value of regressor. In contrast to linear regression, we could directly see that the interpretation value in the probit regression coefficient was the marginal effect.

Table 2 depicts that each person contributed a marginal effect on both the study areas, namely the city and village. Men in the urban area had a smoking probability of 56.10 percent higher than women. While in rural areas, men had a smoking probability of 56.33 percent higher than women. The age variable in the urban area had no significant impact on the probability of smoking. Conversely, in rural areas, age had a significant positive impact. The addition of one year of age would increase the probability of smoking by 0.01 percent.

The marital status variable had a significant and negative impact in the rural area but did not influence those in urban areas. The probability of not smoking among married individuals was two percent higher than those unmarried. In both regions, the head of a household status variable significantly and positively affected the probability of smoking. In the urban area, the individual status of household heads had a smoking probability of 2.16 percent higher than those not becoming the head of a household. While in the rural area, the probability was 2.07 percent. Education had a significant negative impact in both urban and rural areas. 
The Effect of Socio-Economic Factors on the Individual Smoking Status: ...

Table 2 Marginal Effect of the Probit of Individuals' Smoking Status in Urban and Rural

\begin{tabular}{lccc} 
Areas & \multicolumn{3}{c}{} \\
\hline Variable & Urban & Marginal Effect dy/dx & Urban+Rural \\
\hline gender & $0.5610^{* * *}$ & $0.5633^{* * *}$ & $0.5673^{* * *}$ \\
& $(0.0075)$ & $(0.0078)$ & $(0.0054)$ \\
age & -0.0002 & $0.0011^{* * *}$ & $0.0004^{*}$ \\
marital & $(0.0003)$ & $(0.0003)$ & $(0.0002)$ \\
& 0.0146 & $-0.0207^{*}$ & 0.0022 \\
hh_head & $(0.0094)$ & $(0.0109)$ & $(0.0070)$ \\
& $0.0216^{* *}$ & $0.0207^{*}$ & $0.0202^{* * *}$ \\
educ & $(0.0100)$ & $(0.0107)$ & $(0.0073)$ \\
& $-0.0134^{* * *}$ & $-0.0085^{* * *}$ & $-0.0119^{* * *}$ \\
income & $(0.0010)$ & $(0.0011)$ & $(0.0007)$ \\
& -0.0030 & -0.0045 & $-0.0057^{* *}$ \\
jawa & $(0.0036)$ & $(0.0036)$ & $(0.0025)$ \\
& -0.0133 & $-0.0641^{*}$ & -0.0320 \\
sumatera & $(0.0307)$ & $(0.0344)$ & $(0.0233)$ \\
& 0.0364 & 0.0181 & 0.0385 \\
kalimantan & $(0.0325)$ & $(0.0356)$ & $(0.0244)$ \\
& -0.0313 & $-0.1101^{* * *}$ & $-0.0646^{* *}$ \\
bali_nusa & $(0.0340)$ & $(0.0365)$ & $(0.0252)$ \\
& $-0.0630^{*}$ & $-0.0912^{* *}$ & $-0.0685^{* * *}$ \\
sula_malu & $(0.0324)$ & $(0.0356)$ & $(0.0243)$ \\
& 0.0041 & $-0.1079^{* *}$ & -0.0338 \\
& $(0.0379)$ & $(0.0472)$ & $(0.0299)$ \\
\hline Source: & & &
\end{tabular}

Source: STATA 14.0, processed (2020)

Dependent Variable: Individual smoking status (smoking)

Note: Sign () describes as a robust standard error

*Significant to $\alpha=10 \%,{ }^{* *}$ Significant to $\alpha=5 \%, * * *$ Significant to $\alpha=1 \%$

Increasing the duration of education for one year would reduce the probability of smoking by 1.34 percent in the urban area and 0.85 percent within rural areas. The income variable did not significantly affect the probability of smoking in both rural and urban areas. Individuals with tribes on Bali and Nusa Tenggara Islands had a probability of smoking by 6.3 percent lower in the urban area and 9.1 percent lower in the rural area than those with tribes on other islands.

\section{Discussion}

Cigarettes as a commodity consumed by many people are indeed a matter of debate. The health perspective mentions that smoking can interfere with health, although findings revealed that cigarettes were used as a treatment for chest pain (Budiman \& Onghokham, 1987), and currently, a specific type of cigarette (Devine Kretek) has been used as a cancer treatment by adding a scavenger set that can change the formulation of cigarette smoke (Zahar, 2011).

This research discovered that age had a significant relation with the probability of smoking. The addition of one year of age would increase the probability of smoking by 0.01 percent in the urban area. These results indicate that the probability of smoking increases with age. Previous research disclosed an inverse $U$ relationship between age 
and smoking participation with the highest number at $45-54$ years (Hu et al., 1995). The probability of smoking would increase to a certain age, then decrease slowly with increasing age (Harahap, 2003).

The addition of age is closely related to the education level. Age and education usually have a positive correlation, where the higher the education level, the older the age. This study uncovered a negative relationship between education and the probability of smoking in both urban and rural areas. The increase in one-year-education would reduce the probability of smoking as much as 1.34 percent in urban areas and 0.85 percent in rural areas. Several previous studies demonstrated a negative correlation between education and smoking probability (Harahap, 2003; Ahsan, 2006; Widyaningrum \& Yu, 2018; Nugroho, 2020). The decrease in the probability of smoking in line with the increase in education was highly related to the independence of smoking decisions (Harahap, 2003). Highly educated individuals are likely to be more independent in deciding to smoke or not smoke than in the high school group, which is more determined by the peer group. Men had a probability of smoking higher than women. This study discovered that gender significantly influenced the probability of smoking. Previous research also found a relationship between gender and the probability of smoking (Ahsan, 2006; Kostova et al., 2011; Nargis et al., 2014; Wang et al., 2018; Kusumawardani et al., 2018). Men had a probability of smoking by 56.10 percent higher than women in the urban area and 56.33 percent higher than women in rural areas.

Men are more aware of the positive effects of smoking, such as being more confident, looking manly, creating a positive mood, relieving stress/difficulties, increasing concentration, and getting along, especially getting more friends (Sugiharti, Sukartini, \& Handriana, 2015). Peer groups are a means of socializing smoking behavior (Harahap, 2003). Smoking behavior is also a learned behavior and is passed down from generation to generation (Komasari and Helmi, 2000).

This research unveiled that Bali and Nusa Tenggara significantly influenced the probability of smoking in urban and rural areas. Individuals with tribes on these islands had a probability of smoking by 6.3 percent lower in urban areas and 9.1 percent lower in rural areas than those with tribes in other islands in urban areas. Individuals by tribes residing in rural areas in Java, Kalimantan, Sulawesi, and Maluku had a lower smoking probability of 6.4 percent, 11 percent, and 10.7 percent, respectively than those outside the region. The significant and negative relationship between tribes in Bali and Nusa Tenggara with the probability of smoking in urban and rural areas indicates a relationship with smoking prevalence and low average cigarette consumption in the region (Indonesian Ministry of Health, 2013). Based on Indonesian Basic Health Research (Riskesdas) (2013) data, regions with tribes on Java, Kalimantan, Sulawesi, and Maluku, with significant results only in rural areas, had a higher smoking prevalence and average consumption than in Bali and Nusa Tenggara. 


\section{Conclusion}

In conclusion, sex, the head of a household status, and education significantly impacted the probability of smoking in the cities and villages. Meanwhile, age, marital status, and almost all tribes' locations revealed significant results only in the village area. The significant negative value of the education variable implies that education is a big deal in reducing smoking prevalence. The income of an individual had no significant impact on the probability of smoking, meaning that the amount of income did not influence smoking behavior. It happened because Indonesia's cigarette consumption ranks fourth globally. People become addicted to cigarettes. As a result, young and new smokers increased in number. Therefore, education regarding the dangers of smoking must be improved immensely to preserve young people.

\section{References}

Ahsan, A. (2018). Peran kekuatan-kekuatan politik dalam perdebatan tarif cukai rokok maksimal pada pembahasan undang-undang no. 39 tahun 2007 tentang cukai. Dissertation. Universitas Indonesia.

Barik, A., Rai, R. K., Gorain, A., Majumdar, S., \& Chowdhury, A. (2016). Socioeconomic disparities in tobacco consumption in rural India : evidence from a health and demographic surveillance system. Perspectives in Public Health, 136(5), 278-287. https://doi.org/10.1177/1757913915609947

Becker, G. S., \& Murphy, K. M. (1988). A theory of rational addiction. Journal of Political Economy, 96(4), 675-700. https://doi.org/10.1086/261558

Bosdriesz, J. R., Mehmedovic, S., Witvliet, M. I., \& Kunst, A. E. (2014). Socioeconomic inequalities in smoking in low and mid-income countries : positive gradients among women?. International Journal for Equity in Health, 13(1), 1-9. https://doi.org/10.1186/1475-9276-13-14

Budiman, A., \& Onghokham. (1987). Rokok kretek lintasan sejarah dan artinya bagi pembangunan bangsa dan negara. Jakarta: PT. Djarum. Kudus.

Central Bureau of Statistics. (2018). Ringkasan eksekutif pengeluaran dan konsumsi penduduke Indonesia. Jakarta: Central Bureau of Statistics.

Doku, D., Koivusilta, L., Rainio, S., \& Rimpela, A. (2010). Socioeconomic differences in smoking among finish adolescents from 1977 to 2007. Journal of Adolescent Health, 47(5), 479-487. https://doi.org/10.1016/i.jadohealth.2010.03.012

Eriksen, M., Mackay, J., Schluger, N., Gomeshtapeh, F. I. \& Drope, J. (2015). The Tobacco Atlas: Fifth Edition. Atlanta: American Cancer Society Inc.

Garrett, B. E., Dube, S. R., Trosclair, A., Caraballo, R. S., \& Pechacek, T. F. (2011). Cigarette Smoking-United States, 1965-2008. Morbidity and Mortality Weekly Report, 60(1), 109113. Retrieved from https://www.cdc.gov/mmwr/preview/mmwrhtml/su6001a24.htm

Gibson, L. (2017). Towards a More Equal Indonesia: How the government can take action to close the gap between the richest and the rest. (February). Oxfam Briefing Paper. Retrieved from https://www-cdn.oxfam.org/s3fs-public/bp-towards-more-equal-indonesia-230217en $0 . p d f$

Hanibuchi, T., Nakaya, T., \& Honjo, K. (2016). Trends in socioeconomic inequalities in selfrated health, smoking, and physical activity of Japanese adults from 2000 to 2010. 
SSM-Population Health, 2, 662-673. https://dx.doi.org/10.1016\%2Fj.ssmph.2016.09.002

Harahap, A. M. (2003). Faktor-faktor yang mempengaruhi besarnya konsumsi rokok individu model sample selection. Thesis Universitas Indonesia. Depok.

Hiscock, R., Bauld, L., Amos, A., \& Platt, S. (2012). Smoking and socioeconomic status in England : the rise of the never smoker and the disadvantaged smoker. Journal of Public Health, 34(3), 390-396. https://doi.org/10.1093/pubmed/fds012

Hosseinpoor, A. R., Parker, L. A., d'Espaignet, E. T., \& Chatterji, S. (2012). Socioeconomic inequality in smoking in low-income and middle-income countries : results from the world health survey. PloS One, 7(8), 1-20. https://doi.org/10.1371/journal.pone.0042843

Indonesian Ministry of Health. (2007). Indonesia Basic Health Research (RISKESDAS) 2007. Jakarta.

Indonesian Ministry of Health. (2010). Indonesia Basic Health Research (RISKESDAS) 2010. Jakarta.

Indonesian Ministry of Health. (2013). Indonesia Basic Health Research (RISKESDAS) 2013. Jakarta.

Indonesian Ministry of Health. (2016). National Health Indicator Survey (Sirkesnas) 2016.

Indonesian Ministry of Health. (2018). The Main Results of Indonesia Basic Health Research 2018. Jakarta.

Jamal, A., King, B. A., Neff, L. J., Whitmill, J., Babb, S. D., \& Graffunder, C. M. (2016). Current Cigarette Smoking Among Adults United States, 2005-2015. Morbidity and Mortality Weekly Report, 65(44). Centers for Disease Control and Prevention. Retrieved from https://www.cdc.gov/mmwr/volumes/65/wr/mm6544a2.htm

John, R., Ross, H., \& Blecher, E. (2012). Tobacco expenditures and its implications for household resource allocation in Cambodia. Tobacco Control, 21(3), 341-346. Retrieved from http://www.jstor.org/stable/41516453

Komasari, D., \& Helmi, A. F. (2000). Faktor-faktor penyebab perilaku merokok pada remaja. Jurnal Psikologi, 27(1), 37-47. https://doi.org/10.22146/jpsi.7008

Kosen, S., Tharany, H., Kusumawardani, N., \& Martini, S. (2016). Health and economic cost of tobacco in Indonesia. Lembaga Penerbit Badan Penelitian dan Pengembangan Kesehatan. https://isbn.perpusnas.go.id/Account/SearchBuku?searchCat=ISBN\&searchTxt=97 $\underline{8-602-373-105-3}$

Kostova, D., Ross, H., Blecher, E., \& Markowitz, S. (2011). Is youth smoking responsive to cigarette prices? Evidence from low-and middle-income countries. Tobacco Control, 20(1), 419-425. https://doi.org/10.1136/tc.2010.038786

Kusumawardani, N., Tarigan, I., Suparmi, \& Schlotheuber, A. (2018). Socioeconomic, demographic and geographic correlates of cigarette smoking among Indonesian adolescents: results from the 2013 Indonesian Basic Health Research (RISKESDAS) survey. Global Health Action, 11(1), 54-62. https://dx.doi.org/10.1080\%2F16549716.2018.1467605

Lantz, P. M., House, J. S., Lepkowski, J. M., Williams, D. R., Mero, R. P., \& Chen, J. (1998). Socioeconomic factors, health behaviors, and mortality prospective study of us adults. Jama, 279(21), 1703-1708. https://doi.org/10.1001/jama.279.21.1703

Lemstra, M., Mackenbach, J., Neudorf, C., Nannapaneni, U., \& Kunst, A. (2009). Daily smoking in saskatoon: the independent effect of income and cultural status. Canadian Journal of Public Health, 100(1), 51-54. https://dx.doi.org/10.1007\%2FBF03405493

Mukong, A. K., \& Tingum, E. N. (2019). The demand for cigarettes : New evidence from South Africa the demand for cigarettes: New evidence from South Africa. Development Southern Africa, 37(1), 1-15. https://doi.org/10.1080/0376835X.2019.1640108 
Nagelhout, G. E., de Korte-de Boer, D., Kunst, A. E., van der Meer, M. R., de Vries, H., van Gelder, B. M., \& Willemsen, M. C. (2012). Trends in socioeconomic inequalities in smoking prevalence, consumption, initiation, and cessation between 2001 and 2008 in the Netherlands. Findings from a national population survey. BMC Public Health, 12(1), 303-323. https://doi.org/10.1186/1471-2458-12-303

Nargis, N., Ruthbah, U. H., Hussain, A. K. M. G., Fong, G. T., Huq, I., \& Ashiquzzaman, S. M. (2014). The price sensitivity of cigarette consumption in Bangladesh : evidence from the International Tobacco Control (ITC) Bangladesh Wave 1 (2009) and Wave 2 (2010) Surveys. Tobacco Control, 23(1), 39-47. https://doi.org/10.1136/tobaccocontrol2012-050835

Nketiah-Amponsah, E., Afful-Mensah, G. \& Ampaw, S. (2018). Determinants of cigarette smoking and smoking intensity among adult males in Ghana. BMC Public Health. 18, 941-962. https://doi.org/10.1186/s12889-018-5872-0

Nugroho, P. A. (2017). Faktor-faktor yang mempengarugi status merokok di Indonesia: studi kasus individu dalam rumah tangga Indonesia family life survey (IFLS) tahun 2014. Undergraduate Thesis. Universitas Muhammadiyah Yogyakarta.

Schaap, M. M., Kunst, A. E., Leinsalu, M., Regidor, E., Espelt, A., Ekholm, O., Helmert, U., Klumbiene, J., \& Mackenbach, J. P. (2009). Social Science \& Medicine Female eversmoking, education, emancipation and economic development in 19 European countries. Social Science \& Medicine, 68(7), 1271 -1278. https://doi.org/10.1016/j.socscimed.2009.01.007

Siahpush, M., Farazi, P. A., Maloney, S. I., Dinkel, D., Nguyen, M. N., \& Singh, G. K. (2018). Socioeconomic status and cigarette expenditure among US households: results from 2010 to 2015 Consumer Expenditure Survey. BMJ Open, 8(6), https://doi.org/10.1136/bmjopen-2017-020571

Sugiharti, L., Sukartini, N. M., \& Handriana, T. (2015). Konsumsi rokok berdasarkan karakteristik individu di Indonesia. Jurnal Ekonomi Kuantitatif Terapan, 8(1), 34-45. https://doi.org/10.24843/JEKT.2015.v08.101.p04

Swe Latt, S., Mohd Rus, R., Ab Rahman, J., Nasreen, H. E., Phyu, H. M. \& Abd. Aziz, K. H. (2015). Nicotine dependency of adult male smokers and its socioeconomic determinants. 18th Family Medicine Scientific Conference 2015, Kuala Terengganu. Retrieved from http://conference2015.fms-malaysia.org/

Wang, Q., Shen, J. J., Sotero, M., Li, C. A., \& Hou, Z. (2018). Income, occupation and education: Are they related to smoking behaviors in China?. PloS One, 13(2), 1-17. https://doi.org/10.1371/journal.pone.0192571

Widyaningrum, N., \& Yu, J. (2018). Tobacco use among the adult Muslim population in Indonesia: a preliminary study on religion, cultural, and socioeconomic factors. Journal of Drug Issues, 48(4), 676-688. https://doi.org/10.1177\%2F0022042618789491

World Health Organization. (2011). Global Adult Tobacco Survey: Indonesia Report 2011. Geneva.

Zahar, G. (2011). The balur and divine kretek therapy (The philosophy and basic ideas). Retrieved from http://smartbio.org/research/the-balur-and-divine-kretek-therapythephilosophy-and-basic-ideas/ 